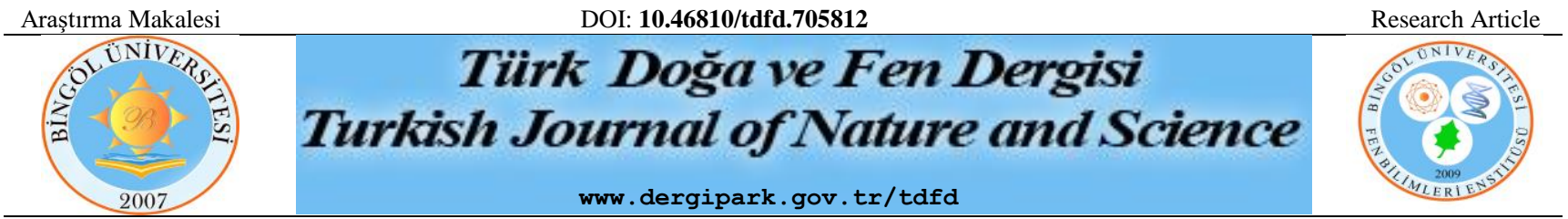

\title{
Neoechinorhynchus rutili (Acanthocephala) ile Enfekte Capoeta trutta (Heckel,1843)'daki Değişikliklerin Biyokimyasal ve Histopatolojik Olarak İncelenmesi
}

\author{
Abdurrahman GÜL ${ }^{1}$, Hayati YÜKSEL ${ }^{2}$, Cebrahil TÜRK $^{3}$, Cüneyt ÇAĞLAYAN ${ }^{4} *$ \\ ${ }^{1}$ Bingöl Üniversitesi, Veteriner Fakültesi, Parazitoloji Anabilim Dalı, Bingöl, Türkiye \\ ${ }^{2}$ Bingöl Üniversitesi, Veteriner Fakültesi, Patoloji Anabilim Dalı, Bingöl, Türkiye \\ ${ }^{3}$ Bingöl Üniversitesi, Genç Meslek Yüksekokulu, Su Ürünleri Programı, Bingöl, Türkiye \\ ${ }^{4}$ Bingöl Üniversitesi, Veteriner Fakültesi, Biyokimya Anabilim Dalı, Bingöl, Türkiye \\ Abdurrahman GÜL ORCID No: 0000-0003-4055-0229 \\ Hayati YÜKSEL ORCID No: 0000-0002-1724-1770 \\ Cebrahil TÜRK ORCID No: 0000-0001-7061-4858 \\ Cüneyt ÇAĞLAYAN ORCID No: 0000-0001-5608-554X \\ *Sorumlu yazar: ccaglayan@bingol.edu.tr
}

(Alınış: 18.03.2020, Kabul: 31.05.2020, Online Yayınlanma: 18.06.2020)

Anahtar Kelimeler
Capoeta trutta,
Neoechinorhynchus
rutili,
Biyokimyasal
Değişiklikler,
Histopatoloji

Anahtar Kelimeler

Capoeta trutta,

rutili,

Değişiklikler,

Histopatoloji
Öz: Bu çalışmada, Murat Nehri'nden temin edilen 30 adet Capoeta trutta'da (Karabalık) tespit edilen Neoechinorhynchus rutili'nin (Acanthocephala) parazitolojik olarak dağılımı incelendi. Ayrıca parazitle enfekte balıkların bağırsak dokularının biyokimyasal ve histopatolojik yönden incelenmesi amaçlandı. Parazit yaygınlığ $1 \% 66.6$, ortalama yoğunluğu 38.5 ve ortalama bolluğu 25.66 olarak hesaplandı. Çalışmada; 1. Grup (Kontrol); parazitle enfekte olmayan balıklar, 2. Grup (parazitle az enfekte balık grubu); 30 parazitten az balıklar, 3. Grup (parazitle çok enfekte balık grubu); 30'dan fazla parazit olan balıklar olarak 3 gruba ayrıldı. Bağırsak dokusundaki süperoksit dismutaz (SOD), katalaz (KAT) ve glutatyon peroksidaz (GPx) enzim aktiviteleri 1. ve 3. gruplar ile kıyaslandığında 2. Grupta daha düşük bulundu $(\mathrm{p}<0.05)$. Glutatyon $(\mathrm{GSH})$ seviyesi enfekte balık gruplarına göre 1. Grupta daha düşük tespit edildi. Malondialdehit (MDA) seviyesinin 1. Grup ile kıyaslandığında, 2. ve 3. Gruplarda daha yüksek olduğu saptandı $(p<0.05)$. Histopatolojik yönden yapılan incelemede kontrol grubuna göre enfekte balıkların bağırsaklarında patolojik değişikliklerin daha belirgin olduğu tespit edildi. Bu çalışmanın sonuçlarına göre $N$. rutili ile enfekte balıklarda parazit yoğunluğuna göre biyokimyasal ve histopatolojik değişimlerin olduğu gözlendi.

\section{Biochemical and Histopathological Examination of Changes in Infected Capoeta trutta (Heckel, 1843) with Neoechinorhynchus rutili (Acanthocephala)}

Keywords
Capoeta trutta,
Neoechinorhynchus
rutili,
Biochemical
Changes,
Histopathology

Keywords Capoeta trutta, Neoechinorhynchus

Biochemical Histopathology

\begin{abstract}
In this study, the parasitological distribution of Neoechinorhynchus rutili (Acanthocephala) detected in 30 Capoeta trutta (Karabalık) obtained from the Murat River was examined. In addition, it was aimed to examine the intestinal tissues of parasitically infected fish in terms of biochemical and histopathology. Parasite prevalence was calculated as $66.6 \%$, average density 38.5 and average abundance 25.66. This study was divided into three groups, respectively. Group 1 (control); fish that are not infected with parasites, group 2 (fish group that is less infected with parasites); fish less than 30 parasites, group 3 (very infected fish group with parasite); fish with more than 30 parasites. The enzyme activities of superoxide dismutase (SOD), catalase (CAT) and glutathione peroxidase (GPx) in intestinal tissue were lower in group 2 compared to groups 1 and 3 ( $p<0.05)$. Glutathione (GSH) level was found lower in group 1 than in infected fish groups. The level of malondialdehyde (MDA) was found to be higher in groups 2 and 3 compared to group 1 ( $\mathrm{p}<0.05$ ). Histopathologically, it was determined that pathological changes in the intestines of infected fish were more pronounced than the control group. According to the results of this study, biochemical and histopathological changes were observed in fish infected with $N$. rutili according to the parasite density.
\end{abstract}




\section{GíRiş}

İnsan beslenmesinde önemli bir protein kaynağı olan balık, yaşadığı ortamda çeşitli olumsuz faktörlerden etkilenmektedir. Sucul ekosistemlerde yetersiz beslenme ve çevresel koşulların değişkenliği balık sağlı̆̆ı üzerinde bazen olumsuz etkilere neden olabilir. Bu gibi durumlar balıklarda paraziter hastalıkların yoğun görülmesine neden olabilmektedir [1,2]. Hızlı gelişen balıkçılık sektörü açısından paraziter balık hastalıklarının belirlenmesi ve neden oldukları olumsuz etkilerin araştırılması büyük önem taşımaktadır. Balıkları enfekte eden paraziter türlerden biri de Neoechinorhynchus rutili (Acanthocephale)'dir. Bazı cyprinidlerde, özellikle Capoeta trutta'da (Karabalık) görülen $N$. rutili'nin varlığı yaygın olarak bildirilmektedir $[3,4]$. Bazı deniz ve tatlı su balıklarının bağırsaklarında Neoechinorhynchus soyuna ait türlerin bulunduğu tespit edilmiştir. Parazitin larvaları oval formda olup, ergin form ile benzerlik gösterir. $N$. rutili'nin, dişileri 5-10 mm uzunluğunda iken, erkekleri 2-6 mm uzunluğundadır. Vücut genellikle ventrale doğru kıvrılmış olup, arka uca doğru inceldiği rapor edilmiştir. Parazitin tutunmasına yarayan hortum (proboscis) çok kısa olup, üzerinde üçer çengelden oluşan altı sıra vardır [4-6].

N. rutili'nin balıklarda gelişme geriliği ve üreme sorunları gibi zararlı etkilere neden olmasının yanı sıra yoğun bulunmalarında ise balık ölümlerine neden olmaktadır. Parazitin hortumu kısa olduğundan, balığın bağırsak mukozasına sığ olarak yapışarak değişik seviyelerde yangıya sebep olmaktadır. Böylece meydana gelen kayıplar, ekonomik zararlara yol açmakta ve verimi azaltmaktadır $[2,4,6,7] . \quad N$. rutili ile ilgili bölgemizde ve farklı bölgelerde birçok çalışma bulunmasına rağmen [3-7] parazitin Capoeta trutta üzerindeki biyokimyasal ve histopatolojik etkileri tam olarak ortaya konulmamış ve sınırlı sayıda çalışmalara rastlanmıştır.

Bu çalışma ile N. rutili ile enfekte Capoeta trutta'daki değişikliklerin biyokimyasal ve histopatolojik olarak araştırılması amaçlanmıştır.

\section{MATERYAL VE METOT}

\subsection{Balıkların Temini ve Parazitolojik Muayene}

Bingöl Üniversitesi Etik Kurulunca (Sayı No: 2017/02/01) onaylanan çalışma av yasağının olmadı $\breve{g ̆}_{1}$ dönemde, Murat Nehri'nden ( $38^{\circ} 56^{\prime} 18.08^{\prime \prime}$ Kuzey, 40 ${ }^{\circ}$ $38^{\prime}$ 57.66" Doğu, yükseklik $1091 \mathrm{~m}$ ve $38^{\circ} 48^{\prime} 24.44^{\prime \prime}$ Kuzey, 40 33' 18.05" Doğu, yükseklik 1003 m) serpme ağıyla avlanan 30 adet Capoeta trutta üzerinde yürütüldü. Balıklar 50 litrelik polietilen torbalar içinde canlı olarak Bingöl Üniversitesi, Veteriner Fakültesi Su Ürünleri Laboratuvarına getirildi. 600 litre hacminde su giriş ve çıkış düzeneği bulunan fiberglas tanklarda muhafaza edildi. Balıkların Geldiay ve Balık'a göre tür teşhisi yapıldı [8]. Balıkların total, çatal ve standart boyları ölçüm tahtası kullanılarak tespit edildi. Vücut ağırlıkları dijital terazi ile ölçüldü.

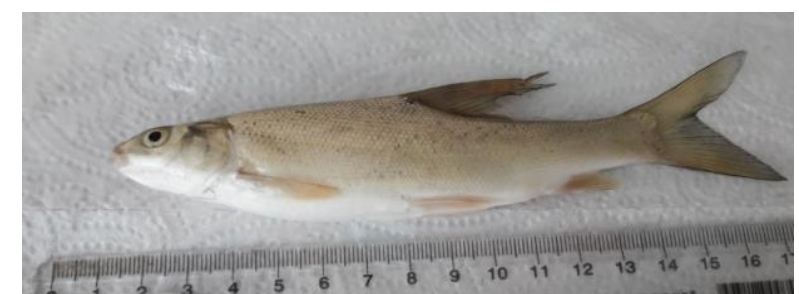

Şekil 1. Karabalık (Capoeta trutta) görünüşü

Çalışmada balıklar Brown'a göre trikain metan sülfanat (MS222) anestezisi altında ötenazi edilerek nekropsileri yapıld1 [9]. Nekropside balıkların sindirim sisteminde $N$. rutili olup olmadığını görebilmek için ürogenital açıklıktan itibaren anteriördeki farinks seviyesine kadar uzunlamasına disseksiyon yapılarak karın boşluğu açıldı. Açılan karın boşluğundan bağırsak dokular dikkatlice alındı ve bir petri kabına konulup parazitolojik yönden incelendi. Bunu takiben fizyolojik su ortamında bağırsaklar cam petri kaplarına alınarak $N$. rutili olup olmadığına bakıldı. Balıkların parazitolojik durumu belirlenerek, $N$ rutili teşhisi; Ekingen [10] ve Williams'a [11] göre yapıld1.

Balıklar, N. rutili yoğunluğuna göre; parazitli olmayan (kontrol), az parazitli ve çok parazitli olmak üzere üç gruba ayrildı.

1. Grup (Kontrol grubu): Enfekte olmayan sağlıklı balık $(\mathrm{n}=10)$.

2. Grup (Parazitle az enfekte balık grubu): N. rutili sayısı az olan $(<30$ adet $)$ enfekte balık $(n=10)$.

3. Grup (Parazitle çok enfekte balık grubu): N. rutili sayısı çok olan ( $>30$ adet) enfekte balık $(n=10)$.

Tüm gruplardaki balıklardan alınan bağırsak dokuları biyokimyasal ve histopatolojik değişikliklerin incelenmesi için alındı.

\subsection{Biyokimyasal Analizler İçin Doku Örneklerinin Hazırlanması}

Balıklardan alınan bağırsak dokusu biyokimyasal tahliller için alınarak deneyler yapılıncaya kadar $-20{ }^{\circ} \mathrm{C}$ ' de muhafaza edildi. Sonrasinda bu dokular dolaptan çıkarılarak sıvı azot yardımıyla porselen havanda toz haline getirildi. $\mathrm{Bu}$ dokular $\% 1.15$ potasyum klorür (KCI) ile belli oranlarda dilüe edilerek ultra turrax cihazı (IKA T-18 BASIC) ile homojenize hale getirildi. Elde edilen homojenat $3500 \mathrm{rpm}$ ' de $15 \mathrm{dk}$. santrifüj edilerek süpernatant kısım malondialdehit (MDA), süperoksit dismutaz (SOD), katalaz (KAT), glutatyon peroksidaz $(\mathrm{GPx})$, glutatyon $(\mathrm{GSH})$ ve protein tayini için kullanıldı.

\subsection{Biyokimyasal Analizler}

Bağırsak doku homojenatındaki SOD aktivitesi Sun ve ark. yöntemine göre ölçüldü [12]. Enzimin birimi U/g protein olarak belirtildi. KAT aktivitesi Aebi'nin metoduna göre ölçüldü. KAT, hidrojen peroksit $\left(\mathrm{H}_{2} \mathrm{O}_{2}\right)$ yıkımını katalize eder. KAT tarafindan $\mathrm{H}_{2} \mathrm{O}_{2}$ 'in yıkım hızı, $\mathrm{H}_{2} \mathrm{O}_{2}$ 'in $240 \mathrm{~nm}$ 'de 1 şı ğ 1 absorbe etmesinden yararlanılarak spektrofotometrik olarak ölçüldü [13]. Birimi katal/g protein olarak ifade edildi. GPx aktivitesi Lawrence ve Burk'un belirlediği yönteme göre ölçülüp, $\mathrm{U} / \mathrm{g}$ protein olarak ifade edildi [14]. GSH düzeyleri 
Sedlak ve Lindsay metoduna göre ölçüldü [15]. Birimi $\mathrm{nmol} / \mathrm{g}$ doku olarak ifade edildi. Bağırsak dokusunda oluşan lipid peroksidasyon derecesini anlamak için doku homojenatında MDA seviyesi incelendi. MDA tayini Placer ve ark. tarafından geliştirilen metoda göre yapıldı. $\mathrm{Bu}$ yöntemde MDA bir lipid peroksidasyon aldehit ürünüdür ve bu yönteme göre tiyobarbitürik asit (TBA) ile analiz sırasında pembe renkli olan bir yapı oluşumu gözlenir. Oluşan bu çözeltinin absorbansı 532 nm'de dalga boyunda ölçüldü [16]. MDA seviyesi nmol/g doku olarak ifade edildi. Bağırsak dokusundaki protein miktarı Lowry ve ark. yöntemine göre ölçüldü [17].

\subsection{Histopatolojik Analizler}

Nekropsi sonucu, balıklardan bağırsak örnekleri alındı. Alınan örnekler \% 10'luk tamponlu formaldehit solüsyonunda tespit edildi. Kırksekiz saatlik tespit işlemini takiben, rutin doku takibi amacıyla değişen derecelerde $(\% 70,80,90,100)$ alkol, ksilol ve parafin serisi içeren ototeknikon cihazına (TP 1020, Leica, Almanya) alındi. Hazırlanan parafin bloklar (327212, Sigma, Almanya) rotary mikrotom ile (RM 2155, Leica, Almanya) 5 mikrometre $(\mu \mathrm{m})$ kalınlığında kesildi. Alınan parafin kesitler Hematoksilen-Eosin (H\&E) ile boyanarak 1şık mikroskobunda (DM 2500, Leica, Almanya) histopatolojik olarak değerlendirildi.

\section{5. İstatistiksel Analiz}

$\mathrm{Bu}$ çalışmada biyokimyasal verilerin istatistiksel analizi için SPSS 12.0 paket programı kullanıldı. İstatistiksel farklılıklar ve önem seviyeleri "One-way Analysis of Variance (ANOVA)" testi ile belirlenirken gruplar arası farklar için Tukey testi kullanıldı. $\mathrm{p}<0.05$ seviyesindeki sonuçlar önemli kabul edilirken tüm değerler ortalama \pm standart hata ( \pm SEM) olarak verildi.

\section{BULGULAR}

\subsection{Parazitolojik Bulgular}

Çalışmada, 30 adet Capoeta trutta'nın ortalama ağırlıkları $126.9 \pm 68.04 \mathrm{~g}$ ve ortalama uzunlukları 24.4 $\pm 4.87 \mathrm{~cm}$ olarak tespit edildi. $N$. rutili yönünden yapılan parazitolojik incelenmelerde 10 balıkta $N$. rutili'ye rastlanmazken geri kalan 20 balıkta en az 2, en fazla 117 adet olmak üzere toplam 770 adet $N$. rutili balıkların bağırsaklarında tespit edildi.

Tablo 1. Balık ağırlığı, uzunluğu ve N. rutili 'in korelasyon katsayıları

\begin{tabular}{|c|c|c|c|}
\hline & Ăğırlık (g) & $\begin{array}{c}\text { Uzunluk } \\
(\mathbf{c m})\end{array}$ & $\boldsymbol{N}$. rutili sayısı \\
\hline Balık Ağırlı̆̆ & 1,000 & $0,968^{* *}$ & $0,685^{* *}$ \\
\hline Balık Uzunluğu & $0,968^{* *}$ & 1,000 & $0,632^{* *}$ \\
\hline N. rutili sayısı & $0,685^{* *}$ & $0,632^{* *}$ & 1,000 \\
\hline
\end{tabular}

Parazitin tespit işlemlerinin ardında şeffaflaştırma ve boyama işlemlerinin ardından makroskobik ve mikroskobik görüntüleri elde edildi. Parazitin yaygınlığ \% 66.6, ortalama yoğunluğu 38.5 ve ortalama bolluğu 25.66 olarak hesapland. Parazit yoğunluğu ile balık ağırlığı ve balık uzunluğu arasında yapılan istatistiksel analizde aralarındaki ilişkinin anlamlı olduğu tespit edildi.
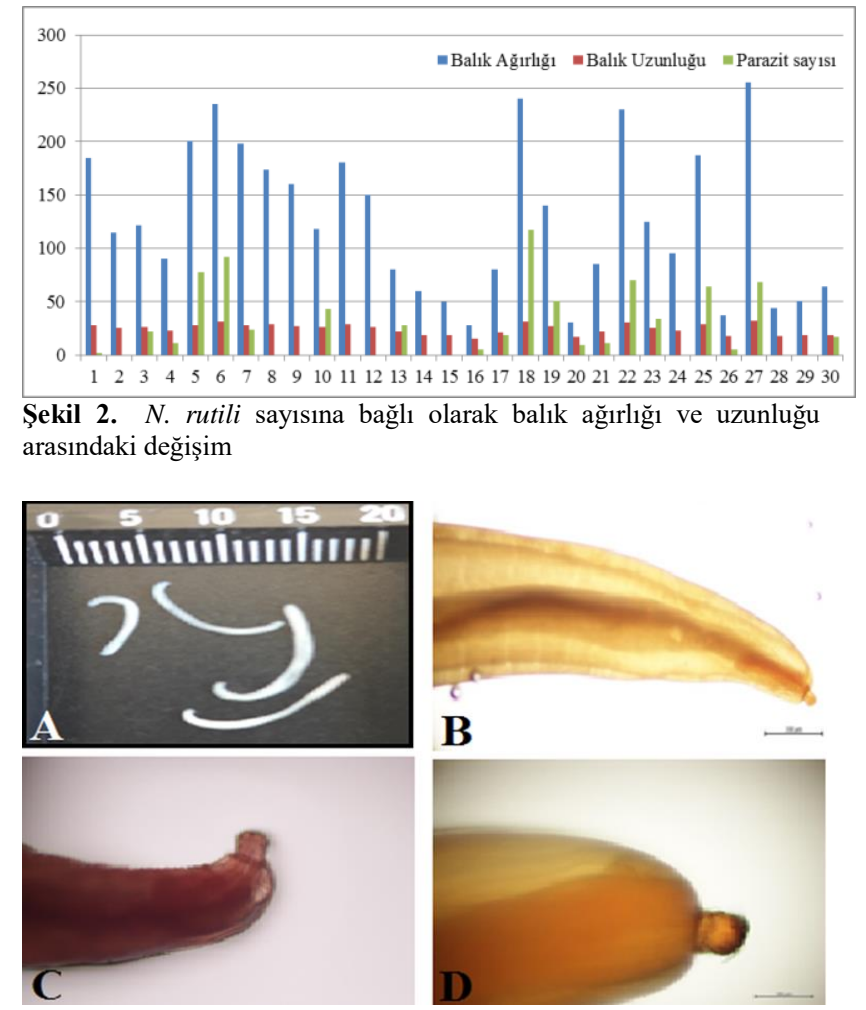

Sekil 3. (A) $N$. rutili'nin makroskobik görünüşü (Orjinal). (B) $N$ rutili'nin mikroskobik görünüşü (Orjinal). (C ve D) $N$. rutili'de proboscislerin görünüşü (Orjinal)

\subsection{Antioksidan Enzim Aktiviteleri}

Antioksidan enzim olarak bilinen SOD aktivitesi incelendiğinde; 1. grup (kontrol) ile karşılaştırıldığında 2. grupta (Parazitle az enfekte balık grubu) daha düşük aktivite gösterdiği tespit edilmiştir $(\mathrm{p}<0.05)$. Öte yandan 3. grubun (Parazitle çok enfekte balık grubu) SOD enzim aktivitesi 1. gruba göre anlamlı derecede yüksek bulunmuştur $(\mathrm{p}<0.05)$ (Şekil 4A).

Hidrojen peroksidin yıkımlanmasından sorumlu enzim olan KAT bağırsak dokusundaki aktivitesi incelendi. KAT enzimi aktivitesi 1. grup ile karşılaştırıldığında 2. grupta daha düşük olduğu tespit edilmiştir $(p<0.05)$. Bununla birlikte, 1. grup ile karşılaştırıldığında 3. grupta KAT enzim aktivitesi anlamlı bir şekilde düşük bulunmuştur $(\mathrm{p}<0.05)$ (Şekil 4B).

GPx enzimi substratı olan GSH varlığında hücrede bulunan $\mathrm{H}_{2} \mathrm{O}_{2}$ 'in detoksifikasyonundan sorumludur. GPx aktivitesi incelendiğinde; 1 . grup ile karşılaştırıldığında 2. grupta daha düşük aktivite gösterdiği tespit edilmiştir $(\mathrm{p}<0.05)$. Diğer taraftan, 1. grup ve 3 . grup arasında istatistiki olarak anlamlı bir fark yoktur. (Şekil 4C). 


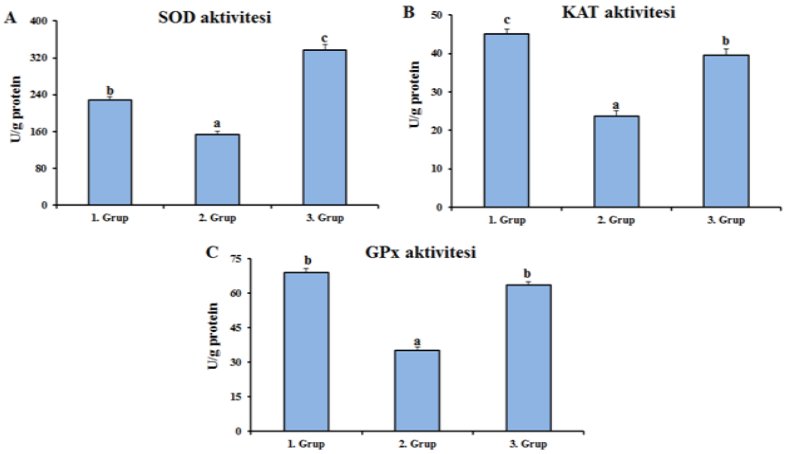

Şekil 4. (A) Capoeta trutta'da N. rutili kaynaklı bağırsak hasarında SOD enzim aktivitesi. (B) Capoeta trutta'da N. rutili kaynaklı bağırsak hasarında KAT enzim aktivitesi. (C) Capoeta trutta'da $N$. rutili kaynaklı bağırsak hasarında GPx enzim aktivitesi. Sutünlarda bulunan $a, b$ ve c harfleri gruplar arasındaki farklılığın önemini göstermektedir $(\mathrm{p}<0.05)$

\subsection{MDA ve GSH Seviyeleri}

Oksidatif hasarın en önemli parametrelerinden biri olan MDA düzeyleri incelendiğinde, 2. ve 3. gruplardaki MDA düzeylerinin 1. gruba göre anlamlı ölçüde arttığı $(\mathrm{p}<0.05)$ tespit edilmiştir. MDA seviyesinin en yüksek değeri 2. grupta bulunmuştur $(\mathrm{p}<0.05)$. Parazitin neden olduğu oksidatif hasarının bu grupta yoğun olduğu tespit edilmiştir (Şekil 5A).
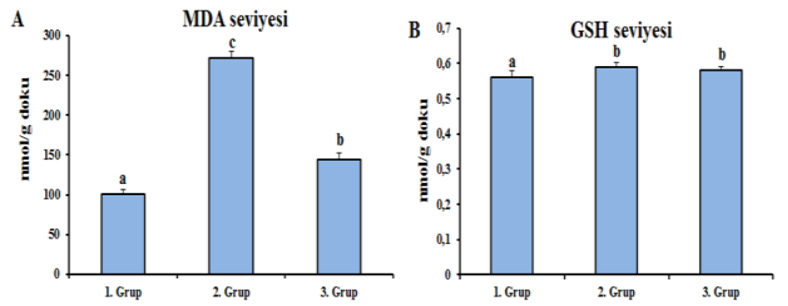

Şekil 5. (A) Capoeta trutta'da $N$. rutili kaynaklı bağırsak hasarında MDA seviyesi. (B) Capoeta trutta'da N. rutili kaynaklı bağırsak hasarında GSH seviyesi. Sutünlarda bulunan a, b ve c harfleri gruplar arasındaki farklılığın önemini göstermektedir $(\mathrm{p}<0.05)$.

Enzimatik olmayan antioksidan olarak bilinen GSH seviyesi incelendiğinde; 2 . ve 3 . gruplardaki GSH seviyeleri 1. gruba göre anlamlı olarak yüksek bulunmuştur $(\mathrm{p}<0.05)$. Bununla birlikte, 2. ve 3. gruplar arasında istatistiki olarak anlamlı bir fark bulunmamıştır (Şekil 5A).

\subsection{Histopatolojik Bulgular}

Çalışmada, 20'si enfekte ve 10'u enfekte olmayan toplam 30 adet Capoeta trutta, N. rutili yönünden makroskobik ve mikroskobik olarak incelendi. Bağırsak lümeninden çıkan $N$. rutili miktarına göre az (1-30 parazit) ve çok (30 ve üzeri parazit) enfekte olmak üzere iki gruba ayrıldı. Enfekte balıkların yapılan sistemik nekropsileri sonunda bağırsak lümenleri açıldığında 0.5 $\mathrm{cm} 1.5 \mathrm{~cm}$ arasında değişen boyutta soluk beyaz renkli parazitlerin bağırsak lümeninde serbest halde bulunduğu saptandı. Bu parazitlerin bağırsak mukozasında dikkati çeken makroskobik bir değişikliğe sebep olmadıkları görüldü. 1. Grup (kontrol) balıkların bağırsaklarının mikroskobik incelemesinde histopatolojik olarak herhangi bir değişikliğin şekillenmediği saptandı (Şekil
6A). Alınan örneklerin mikroskobik incelemesinde, az parazitli grup olarak değerlendirilen balıkların bağırsak mukozalarında epitelin sağlam olduğu lamina propria ve submukozada eozinofil lökosit ile lenfoplazmositer hücrelerden oluşan yangısal bir reaksiyonun geliştiği gözlendi (Şekil 6B). Çok parazitli olarak değerlendirilen grupta ise dört balıkta bağırsak lümeninde granüllü ve eozinofilik boyanan parazit yumurtaları (Şekil 6C), bağırsak mukoza epitelinde desquamasyon ve dejenerasyon (Şekil 6D), lamina propria ve submukozada ise daha yaygın ve şiddetli eozinofil lökosit infiltrasyonu ile lenfosit ve plazma hücrelerden oluşan yangısal bir yanıtın şekillendiği tespit edildi (Şekil 6E). Bu grupta bir balıkta lamina propriada yoğun bir bağ doku artışının şekillendiği ve bağırsak lümeninin daralmasına sebep olduğu gözlendi (Şekil 6F).

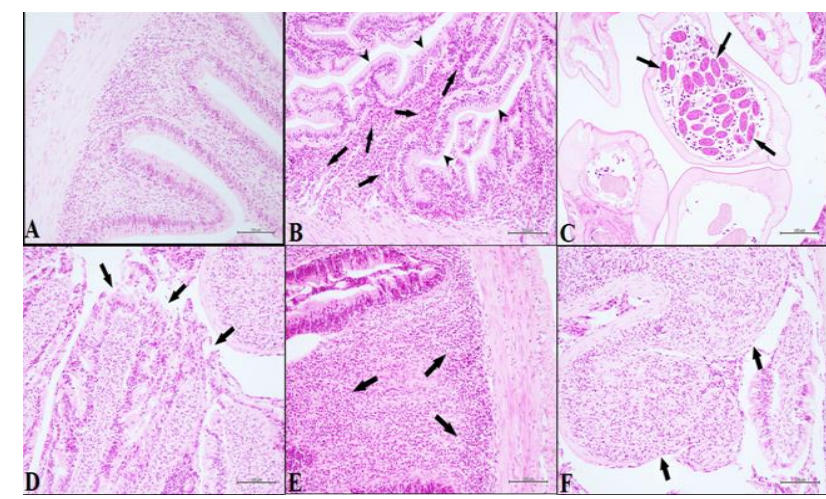

Şekil 6. (A) 1. grup (Kontrol). H\&Ex20 (B) Bağırsak mukoza epiteli (ok başları) ve Lamina Propriada eozinofil lökosit ve lenfo-plazmositer hücre infiltrasyonları (oklar). H\&Ex20 (C) Bağırsak lümeninde kistik bir kese içerisinde granüllü-eozinofilik parazit yumurtaları (oklar). H\&Ex10 (D) Bağırsak mukoza epitelinde desquamasyon ve dejenerasyon (oklar). H\&Ex20 (E) Bağırsak lamina propriasında eozinofil lökosit ve yaygın lenfo-plazmositer hücre infiltrasyonları (oklar). H\&Ex20 (F) Bağırsak lümenine doğru bağ doku artışı ve lümende daralma (oklar). H\&Ex20

\section{TARTIŞMA}

Yapılan birçok çalışmada, değişik balık türleri üzerinde parazitik muayenede, $N$. rutili parazitinin tespit edildiği bildirilmiştir [2-6,18]. Bu çalışmada $N$. rutili'nin Capoeta trutta'daki enfeksiyon oranı \% 66.66 olarak tespit edilmiştir. Elde edilen bu oran, Sağlam ve Sarıeyyüpoğlu [6] \% 43.95, Dörücü ve İspir [5] \% 34.37'lik orandan yüksek, Barata ve Dörücü [3] tarafından bulunan \% 84.12'lik orandan ise düşük bulunmuştur. $\mathrm{Bu}$ farklılı̆̆ın muhtemel nedeni, gerek çalışma alanı gerekse incelenen balık türlerinin beslenme farklılığından kaynaklandığı düşünülmektedir.

Keban Baraj Gölü’nün Koçkale bölgesi’nden avlanan 37 tane Capoeta trutta balığında yapılan araştırma ile $N$. rutili'nin varlığı araştırılmış ve araştırma sonucunda 37 balıktan 14'ünün enfekte olduğu belirlenmiştir. Parazitin yaygınlığını \% 2.70, yoğunluğunu 14 ve bolluğunu 38 olarak bildirmişlerdir [6]. Benzer bir şekilde, Dörücü ve İspir, Keban Baraj Gölü'nde yaptıkları çalışmada, avlanabilen balık türlerinde iç parazitlerin varlığını ve çeşitlerini araştırmış ve inceledikleri 32 Capoeta trutta'da 175 adet $N$. rutili tespit etmişlerdir [5]. Ağrı ili Murat Nehri ile Erzurum ili Aras Nehri'nden temin edilen bazı balıkların endohelmintlerinin araştırılması 
konulu bir çalışmada Aras Nehri'nden temin edilen Capoeta capoeta'larda rastlanan $N$. rutili'nin yaygınlığ $\% 58$, ortalama yoğunluğu 2.2 ve ortalama bolluğu ise 1.3 olarak bulunmuştur [7]. Barata ve Dörücü'nün, Karakaya Baraj Gölü Kömürhan bölgesinden temin edilen 126 adet $C$. trutta balıklarında yaptıkları çalışmada; $106 C$. trutta balığının bağırsağında $N$. rutili'yi tespit etmişlerdir. Çalışmalarında 106 tane enfekte $C$. trutta balığında bulunan $N$. rutili sayıs1 3958 iken, yoğunluğu 37.33, yaygınlığ1 \% 84.12, bolluğu ise 31.41 olarak rapor etmişlerdir [3]. Gül ve ark. Murat Nehri'nde (Genç-Bingöl) yakalanan 91 adet $C$. trutta'dan 40 tanesinin $N$. rutili ile enfekte olduğunu ve toplam parazit sayını 322 olarak belirlemiş, parazit yaygınlığı \% 43.95, yoğunluğu 8.05 , bolluğu ise 3.54 olarak bulunmuştur [4]. Yapılan mevcut çalışmada ise ortalama ağırlıkları $126.9 \pm 68.04 \mathrm{~g}$ ve ortalama uzunlukları $24.4 \pm 4.87 \mathrm{~cm}$ olarak tespit edilen 30 adet C. trutta'nın $N$. rutili yönünden yapılan parazitolojik incelenmelerinde 10 balikta $N$. rutili'ye rastlanmazken geri kalan 20 balıkta en az 2 en fazla 117 adet olmak üzere toplam 770 adet $N$. rutili tespit edilmiştir. Parazitin yaygınlığ $\% 66.6$, ortalama yoğunluğu 38.5 ve ortalama bolluğu 25.66 hesaplanmıştır.

Parazitler yerleştikleri organ, doku ve hücrelerde serbest radikal miktarlarını arttırması sonucu lipid peroksidasyonuna neden olup, konakçıda doku ve hücre hasarının şekillenmesine neden olduğu bildirilmiştir [19]. Artan serbest radikaller hücre membran yapısında bulunan çoklu doymamış yağ asidi zincirinden bir hidrojen atomu uzaklaştırılması yoluyla lipid peroksidasyon olayını başlatırlar. $\mathrm{Bu}$ olayı takiben ortamda lipid peroksidayon son ürünü olan MDA seviyesi artar. MDA seviyesinin artması hücrelerin oksidatif hasara uğradığının en önemli bir kanıtıdır [20]. Yapılan çalışmada 1. grup ile karşılaştırıldığında 2. ve 3. gruplarda MDA seviyesinin yüksek olduğu tespit edilmiştir. Dolayısıyla $N$. rutili ile enfekte olan balık bağırsak dokularında MDA seviyesinin daha yüksek olması, parazitin oksidatif hasarı artırdı̆̆ını göstermektedir.

Glutatyon (GSH), hücrelerde en bol bulunan protein olmayan tiyoldür. GSH, hücreleri, reaktif oksijen türleri (ROS) ve reaktif azot türleri (RNS) dahil olmak üzere eksojen ve endojen toksinlere karşı korur [21-23]. Ayrıca, $\mathrm{H}_{2} \mathrm{O}_{2}$, süperoksit radikalleri ve membran protein tiyolleri gibi serbest radikal türlerin yok edilmesinde de GSH'ın rol oynadığı bildirilmiştir [24]. Mevcut çalışmada 1. grup ile karşılaştırıldığında 2 . ve 3 . gruplarda GSH düzeyinin arttığı saptanmıştır. N. Rutili ile enfekte olan balıkların bağırsak dokusunda parazitin neden olduğu hücresel hasara karşı GSH düzeyleri artmış olup, 2. ve 3. gruplarda aynı etki gözlenmiştir. Parazitik invazyonların bir sonucu olarak gelişen oksidatif stresten doku, organ ve hücrelerin hasar görmesine karşı antioksidan sistemlerin koruyucu bir rol oynadığı bildirilmiştir [25]. Bu bağlamda SOD enzimi süperoksit radikalini moleküler oksijene ve $\mathrm{H}_{2} \mathrm{O}_{2}$ 'e dönüştürür. KAT enzimi ise $\mathrm{H}_{2} \mathrm{O}_{2}$ gibi zararlı bir bileşiği parçalayıp, moleküler oksijene ve suya dönüştürerek oksidatif hasarın derecesini azaltır [26]. Bu enzimler aktif oksijen türlerini ortadan kaldırmak için beraber çalışırlar ve fizyolojik konsantrasyonlarda aktivitelerinin veya miktarlarının azalması sonucu hücresel lipidlerin, proteinlerin ve DNA'nın oksidatif hasardan olumsuz etkilenmelerine neden olurlar [27]. Bir diğer antioksidan enzim olan GPx, substrat olarak kullandığ $\mathrm{GSH}$ varlığında $\mathrm{H}_{2} \mathrm{O}_{2}$ 'in su ve moleküler oksijene dönüşümünü katalize eder [26]. Yapılan çalışmada 1. grup ile karşılaştırıldığında 2. grupta antioksidan enzimler olan SOD, KAT ve GPx aktivitelerinin oldukça düşük olduğu belirlenmiştir. 3. Grupta bulunan SOD enzimi 1. gruba göre istatistiksel olarak daha yüksek aktivite gösterirken, KAT ve GPx enzim aktiviteleri ise daha düşük aktivite göstermiştir. Çalışma sonucunda $N$. rutili ile az enfekte olan balıklarda antioksidan enzim aktivitelerinde daha fazla düşüş yaşanırken, parazitle çok enfekte olan balıkların enzim aktivitelerindeki düşüş daha az gerçekleşmiştir.

Çalışmada parazit tespit edilen balıkların bağırsak lümenlerinde değişen sayıda parazit tespit edildi. Bu balıkların bağırsak mukozalarında makroskobik bir değişikliğe rastlanılmadı. Ancak bu balıkların bağırsaklarının histopatolojik incelemelerinde az parazitli gruptaki balıkların bağırsaklarının mukoza epitelinde bir değişiklik gözlenmezken, çok parazitli grupta ise bağırsak mukoza epitelinde dejenerasyon ve desquamasyon gözlendi. Az parazitli gruptaki balıkların bağırsaklarında submukozada ve lamina propriada gözlenen yangısal değişiklikler, çok parazitli gruptaki balıklara nazaran daha hafif şiddette şekillenmişti. Gruplar arasında gözlenen histopatolojik değişikliklerin şiddetindeki farklılık balıkların maruz kaldığı paraziter enfestasyonun yaygınlığı ve fazlalığına bağlı olabileceğ düşünülmüştür.

\section{SONUÇ}

Sonuç olarak, Murat Nehrinde yaptığımız bu çalışma ile C. trutta'daki $N$. rutili'nin varlığı tespit edilmiş ve parazitin yaygınlığı \% 66.6 olarak belirlenmiştir. Biyokimyasal ve histopatolojik analiz sonuçlarının ise paraziter enfestasyona bağlı olarak değişim göstermiştir.

\section{Teşekkür}

$\mathrm{Bu}$ çalışma Bingöl Üniversitesi Bilimsel Araştırma Projeleri (BAP) birimi tarafından desteklenmiştir (Proje No: BAP-VF.2017.00.002). Katkılarından dolayı BAP birimine teşekkür ederiz.

\section{KAYNAKLAR}

[1] Arda M, Seçer S, Sarıeyyüpoğlu M. Balık Hastalıkları, Medisan Yayın Serisi: 61, II. Bask1 Medisan Yayınevi, Ankara; 2005.

[2] Dezfuli BS. Cypria reptans (Crustacea: Ostracoda) as an intermediate host of Neoechinorhynchus rutili (Acanthocephala: Eoacanthocephala) in Italy. J Parasitol 1996; 82 (3): 503-5.

[3] Barata S, Dörücü M. Karakaya Baraj Gölü Kömürhan bölgesinden yakalanan bazı balıklarda 
endohelmintlerin araștırılması. Fırat Üniv Fen Bil Derg. 2014; 26(1): 59-68.

[4] Gül A, Türk C, İspir Ü, Kırıcı M, Taysı MR, Yonar ME. Murat Nehri'nde (Genç-Bingöl) Avlanan Bazı Cyprinid'lerde Neoechinorhynchus rutili (Müller, 1780) (Acanthocephala)'nin Araştırılması. Erciyes Üniv Vet Fak Derg. 2017; 14(3), 163-8.

[5] Dörücü M, İspir Ü. Keban Baraj Gölü'nden avlanabilen balık türlerinde iç paraziter hastalıkların incelenmesi. Firat Üniv. Fen ve Müh Bil Derg. 2005; 17(2): 400-4.

[6] Sağlam N, Sar1eyyüpoğlu M. Capoeta trutta balığında rastlanan Neoechinorhynchus rutili (Acanthocephala)'nin incelenmesi. T Parazitol Derg. 2002; 26(3): 329-31.

[7] Aslan B. Ağrı ili Murat Nehri ile Erzurum ili Aras Nehri'nden yakalanan bazı balıkların endohelmintlerinin araștırılması, Yüksek Lisans Tezi, Atatürk Üniv. Fen Bil Enst, Erzurum; 2009.

[8] Geldiay R, Balık S. Türkiye Tatlısu Balıkları (Ders Kitab1). III. Baskı. Ege Üniv Su Ürünleri Fak. Yay. 2002.

[9] Brown LA. 1993. Anesthesia and Restraint. In: Fish Medicine M.K. Stoskopf ed. Philadelphia: WB Saunders Company; 79-90.

[10] Ekingen G. Tatlı Su Balık Parazitleri. Fırat Üniv. Su Ürünleri Y.O, Elazığ: Firat Ü. Basımevi, 1983.

[11] Williams H, Jones A. Parasitic Worm of Fish. London and Bristol: Taylor \& Francis, 1994.

[12] Sun Y, Larry WO, Ying L. A simple method for clinical assay of superoxide dismutase. Clin Chem. 1988;34(3):497-500.

[13] Aebi H. Catalase. In: Bergmeyer HU, ed. Methods in Enzymatic Analysis. New York: Academic Press; 1983: 276-86.

[14] Lawrence RA, Burk RF. Glutathione peroxidase activity in selenium-deficient rat liver. Biochem Biophys Res Commun. 1976;71:952-8.

[15] Sedlak J, Lindsay RHC. Estimation of total protein bound and nonprotein sulfhydryl groups in tissue with Ellmann's reagent. Anal Biochem. 1968;25:192-205

[16] Placer ZA, Cushmanni LL, Johnson BC. Estimation of products of lipid peroxidation (as malondialdehyde) in biochemical systems. Anal Biochem. 1966;16:359-64.

[17] Lowry OH, Rosebrough NJ, Farr AL, Randall RJ. Protein measurement with the folin phenol reagent. J Biol Chem. 1951;193:265-75.

[18] Mousavi-Sabet H, Sattari M. First report of Neoechinorhynchus rutili in Cobitis faridpaki (Cobitidae) from the southern Caspian Sea Basin. Croatian J Fisheries. 2013; 71:170-5.

[19] Değer S, Değer Y, Ertekin A, Gül, A, Biçek K, Özdal N. Dictyocaulus viviparus ile Enfekte sığırlarda lipit peroksidasyon ve antioksidan durumunun saptanmasi. Türkiye Parazitol Derg. 2008;32(3):234-37.

[20] Kandemir FM, Küçükler S, Çağlayan C. Beneficial effects of silymarin and naringin against methotrexate-induced hepatotoxicity in rats. Atatürk Üniversitesi Vet Bil Derg. 2017;12(2):16777.
[21] Martin HL, Teismann P. Glutathione - a review on its role and significance in Parkinson's disease. The FASEB journal. 2009;23(10):3263-72.

[22] Özaslan MS, Demir Y, Küfrevioğlu OI, Çiftci M. Some metals inhibit the glutathione S-transferase from Van Lake fish gills. J. Biochem. Mol. Toxic. 2017; 31(11), e21967.

[23] Özaslan MS, Demir Y, Aksoy M, Küfrevioğlu ÖI, Beydemir Ş. Inhibition effects of pesticides on glutathione-S-transferase enzyme activity of Van Lake fish liver. J. Biochem. Mol. Toxic. 2018; 32(9), e22196.

[24] Kandemir FM, Kucukler S, Eldutar E, Caglayan C, Gülçin I. Chrysin protects rat kidney from paracetamol-induced oxidative stress, inflammation, apoptosis, and autophagy: a multibiomarker approach. Sci pharma. 2017;85(1): 4

[25] Dede S, Deger Y, Deger S, Alkan M. Bazı endoparazitlerle (Fasciola sp.+ Trichostrongylidae sp.+ Eimeria sp.) enfekte koyunlarda lipit peroksidasyonu ve antioksidan durumunun saptanmas1. Türkiye Parazitol Derg. 2000;24(1):190-3.

[26] Kirici M, Turk C, Caglayan C, Kirici M. Toxic Effects of Copper Sulphate Pentahydrate on Antioxidant Enzyme Activities and Lipid Peroxidation of Freshwater Fish Capoeta umbla (Heckel, 1843) Tissues. Appl. Ecol. Environ. Res. 2017;15(3):1685-96.

[27] Kaygusuzoğlu E, Caglayan C, Kandemir FM, Yildırım S, Kucukler S, Kilınc MA, et al. Zingerone ameliorates cisplatin-induced ovarian and uterine toxicity via suppression of sex hormone imbalances, oxidative stress, inflammation and apoptosis in female wistar rats. Biomed Pharmacother. 2018;102:517-30. 